J. Clin. Chem. Clin. Biochem.

Vol. 16, 1978, pp. 693-697

\title{
Teaching in Clinical Chemistry: Evolution and Needs ${ }^{1}$ )
}

\author{
By M. Roth \\ University Hospital, Geneva
}

(Received June 8, 1978)

Summary: As a young discipline, clinical chemistry has undergone a rapid expansion since 1950 . The development of suitable teaching programs has not always followed with corresponding speed. Different aspects of teaching in clinical chemistry must be considered:

1. Postgraduate teaching; this may be provided to graduates in medicine, science or pharmacy in view of complementing their respective basic studies by knowledge from the other disciplines. The aim is to form clinical chemists having a good understanding both of medical problems related to the laboratory and of the technical and chemical bases of analytical work.

2. Undergraduate teaching; this refers in particular to the teaching of medical students. Whereas these normally do not need a detailed understanding of methodology, they should be aware of the possibilities and limitations of chemical analyses, so as to make the most effective use of laboratory services.

3. Teaching of technicians. It is essential for the good quality of laboratory work that the technicians be given appropriate courses by qualified teachers, both in the fundamental and practical aspects of clinical chemistry.

Teaching in universities requires the establishment of courses specifically devoted to clinical chemistry; the importance given today to laboratory results and the great variety of instruments and techniques make it essential that high qualification is achieved by those in charge of clinical chemical laboratories.

In developing countries, teaching is often insufficient at present. Here exists a great need for adequate programs and courses in clinical chemistry, both at the technician and graduate level. Due consideration should be given to the particular local conditions.

\section{Ausbildung in Klinischer Chemie: Entwicklung und Bedarf}

Zusammenfassung: Als junges Fach hat sich die klinische Chemie seit 1950 rasch entwickelt. Der Aufbau entsprechender Unterrich tspprogramme ist nicht immer mit der wünschbären Geschwindigkeit erfolgt. Es gibt verschiedene Aspekte der Ausbildung in klinischer Chemie.

1. Fortbildung; diese ist für Diplomierte in Medizin, Chemie oder Pharmażie bestimmt; sie hat den Zweck, die jeweiligen Studien durch Kenntnisse aus den anderen Fachgebieten zu ergänzen. Damit sollen klinische Chemiker mit gutem Verständnis sowohl von Labor-abhängigen medizinischen Problemen wie von den technischen und chemischen Grundlagen der analytischen Arbeit herangebildet werden.

2. Bis zum Diplom; dies betrifft insbesondere den Unterricht für Medizin-Studenten. Während diese normalerweise keine detaillierte Kenntnis der Methoden benötigen, sollen sie mit den Möglichkeiten und Grenzen von chemischen Analysen vertraüt sein, üm die Leistungen des Laboratoriums optimal ausnutzen zu können.

3. Unterricht für technisches Personal. Für eine gute Qualität der Labor-Untersuchungen ist es wesentlich, daß medizinisch-technische Assistenten durch qualifizierte Lehrer fachmännisch unterrichtet werden, sowohl in den grundlegenden wie in den praktischen Aspekten der klinischen Chemie.

1) Lecture delivered at the Xth international Congress of Clinical Chemistry, Mexico-City, March 1st, 1978. 
Der Unterricht in Universitäten verlangt die Schaffung von speziell der klinischen Chemie gewidmeten Vorlesungen; die Bedeutung, die heutzutage den Laborresultaten beigemessen wird, und die Mannigfaltigkeit von Geräten und Methoden machen es unumgänglich, daß die Vorsteher klinisch-chemischer Laboratorien entsprechend qualifiziert sind.

In Entwicklungsländern ist der Unterricht heute oft ungenügend. Hier besteht ein großer Bedarf an adäquaten Programmen und Vorlesungen in klinischer Chemie sowohl für technisches wie akademisches Personal. Die Besonderheiten der örtlichen Verhältnisse müssen berücksichtigt werden.

\section{Introduction}

Clinical chemistry, as a relatively young discipline, has undergone a rapid evolution in recent years. The necessity of teaching the subject has become increasingly evident. An important question is: what should be included in such an educational program, and who are the persons who should receive this teaching? It is perhaps useful, at this point, to try to characterize those persons who essen tially perform clinical chemistry, namely the clinical chemist and the laboratory technician.

Technicians are involved in bench work. They may work within a group supervised by a chief technician or a clinical chemist. In large laboratories, several clinical chemists will in turn be responsible to the laboratory director. Those people acting at the superior level of the hierarchy are supposed to possess a vast knowledge of the various aspects of clinical chemistry, whereas the technicians performing the daily bench work should have the necessary skill and a good understanding of what they do.

What happens in laboratories employing unadequately trained personnel? At the top staff level, a deficient understanding of medical problems results in a bad adaptation of laboratory work to the needs of clinicians. Lack of expertise in instrumentation restricts the choice of methods to those requiring only simple and robust equipment; it makes the laboratory excessively dependent upon external service and maintenance. It prevents the solving of problems revealed by the quality control. Lack of knowledge in chemistry makes it difficult to control the functioning of analytical-chemical processes.

It is not usual in congresses of clinical chemistry to speak about badly working laboratories. However in the present discussion, it may be useful to have a look at such laboratories, and to examine the various forms of incompetence in clinical chemistry laboratories.

The worst among these forms is that of people who are unaware of their own incompetence. It occurs in laboratories lacking adequate quality control.

An almost equally bad situation arises if the laboratory chief is not an expert, and he realizes it. He may then try to employ qualified collaborators, but this occurs rarely. He may also try to acquire additional training, and this is the best thing he can do. Unfortunately, some poorly qualified laboratory chiefs tend to employ collaborators at least as incompetent as themselves, in order to avoid criticism. Such laboratories rely exceedlingly upon costly reagents and push-button machines, and have to restrict themselves to the execution of a limited number of standard procedures.

Too often, poorly qualified laboratory chiefs content themselves by relying entirely upon technicians. The chief technician is then considered a docile substitute to the clinical chemist who would, in fact, be in a better position to express criticism. Such laboratories rarely perform research, nor do they offer that variety of laboratory tests which would meet all the needs of the clinics. This is not to detract from the merit of laboratory technicians, who play an essential role in any good laboratory.

It is obvious that the top laboratory staff must be familiar with the various areas of clinical chemistry, which include a good knowledge of analytical chemistry and of the biochemical aspects of pathology. To us; a clinical chemist is a person who has received an education that makes him capable of efficiently leading the laboratory or to work as an expert staff member. The consequences of insufficient training of staff members are poor laboratory service and dissatisfaction among technicians.

The qualification of technicians is important. The daily performance of analytical work is in their hands. It ultimately depends on them whether errors are corrected or eliminated and whether a satisfactory precision is achieved. Insufficient training of technicians is highly detrimental to the quality of laboratory service. The consequence is that the clinicians distrust the laboratory results.

In recent years, great emphasis has been put on quality control in clinical laboratories. Indeed, a good quality control scheme is now considered essential to the proper functioning of the laboratory. However, quality control merely tells whether the results are precise and accurate or not. If they are not, then measures have to be taken to identify the causes of error and to find appropriate remedies. Such measures require a thòrough knowledge of analytical biochemistry and instrumentation. The 
success of any quality control program ultimately depends on the teaching received by the laboratory personnel.

The question of teaching in clinical chemistry has been an early concern of the International Federation of Clinical Chemistry (IFCC) and of the Section on Clinical Chemistry of the International Union of Pure and Applied Chemistry (IUPAC). In 1967, the IUPAC Section on Clinical Chemistry established a Commission on the Teaching of Clinical Chemistry. At the same time the IFCC appointed a Committee on Education and Training in Clinical Chemistry to collaborate with the IUPAC Commission. It was soon recognized that one task of these Commissions was to define the educational and training processes to prepare future leaders of clinical chemistry. As a part of this task it was essential to gather information about the status of clinical chemistry throughout the world.

The emergence of clinical chemistry as an independent science is the result of contributions from chemistry, medicine and also from related disciplines such as biology, physics, pharmacology and toxicology. Indeed, significant advances in clinical chemistry have often resulted from joint efforts of individuals possessing different professional backgrounds.

The book "Quantitative Clinical Chemistry", by $J$. P. Peters, a physician, and D. D. van Slyke, a chemist (1), greatly contributed to the acceptance of the term clinical chemistry, as a definition of the domain of activity of laboratories performing chemical analyses for the information of clinicians. In the different countries of the world, clinical chemistry is practised by persons of varied background: chemists, physicians and pharmacists, and this variety was also reflected in the membership of the IUPAC-IFCC Teaching Committees. The continuing activity of both Committees over many years has recently resulted in the publication of the monograph "Education and Training for Clinical Chemistry" (2) which presents a survey of the status of clinical chemistry throughout the world, a review of the developments in the field and their influence on professional requiremen ts, and guidelines for the organization of teaching in clinical chemistry. These guidelines have been approved by IUPAC and IFCC and, therefore, represent recommendations of both organizations.

\section{Role of the Clinical Chemist}

A training scheme for clinical chemists requires that the role and nature of the clinical chemist have been defined. These vary from country to country, and if one tries to delineate the overall characteristics of a clinical chemist, one sees that he has first acquired a degree in one of the basic disciplines, medicine, chemistry, biochemistry, pharmacy, or sometimes, biology, which he then supplemented by training in those parts of clinical chemistry not covered by his basic studies. At present, complete academic curricula for clinical chemistry where the entire program is organized around this discipline are available in only a few places.

The role of the clinical chemist is to study and advise on biochemical processes in the tissues and fluids of the human body and the effect of diseases and drugs on these processes. He organizes the routine service of analytical and functional tests; he devises and tests new methods of investigating disease processes. His duties combine laboratory service and development of methods and sometimes include participation in clinical research.

A survey of the regulations regarding clinical chemists around the world has shown that in a number of countries the leadership of clinical chemistry laboratories may be held indifferently by graduates in medicine, chemistry or pharmacy, a supplementary training program being sometimes required. In some other countries, the position is open only to graduates in one of the above disciplines. Such restricting policies have in general reflected the particular interest, be it scientific or professional, of one academic group for clinical chemistry. The IFCC Committee on Education and Training in Clinical Chemistry has provided a forum for presentation and discussion of the various national views regarding the training and the status of the clinical chemist. This has eventually led to the elaboration of guidelines for the training of clinical chemists. Taking advantage of the different professional backgrounds of its members and on the basis of the information provided by the IFCC national adhering societies, the Committee together with the IUPAC Commission on Teaching of Clinical Chemistry has prepared these guidelines which include specific programs to supplement the three primary backgrounds in medicine, chemistry and pharmacy. I shall now present these guidelines.

A number of basic branches essential to the clinical chemist are: mathematics and statistics, general chemistry, analytical chemistry, organic chemistry, physical chemistry and biochemistry; in the physical branches, optics, electricity, electronics and fluid dynamics are of particular importance. The biomedical branches include fundamental biology, cell biology and morphology, physiology, microbiology, pharmacology and pathology. Knowledge of the manifestations of disease and the response to therapy could be most valuable.

One essential function of the clinical chemist is the continuing improvement of methods which makes use of technological developments to provide better information on the biochemical status of the patient. A critical assessment of new techniques and evaluation of instruments require a good knowledge of methodology and a scientific attitude which is best induced by basic research. 
The clinical chemist has to provide the best possible supporting service to his clinical colleagues. He should organize and manage his laboratory in such a way that the results for which he is responsible achieve the standards of quality required by the needs of the clinicians. Reports should be sent early enough to allow for diagnostic and therapeutic measures to follow with the desirable speed. A well-functioning system for emergencies must be organized. All this requires a judicious application of management techniques, practical experience in a good laboratory, and an acute awareness in the problems of the patient and of the clinician. The nonmedical scientist will learn the latter attitude by participation in the clinical activities of a medical center, including attendance at the various medical conferences.

I shall now describe those parts of the guidelines specific for every one of the three basic branches, medicine, chemistry and pharmacy. The recommendation is that in each case the basic studies have to be supplemented by an appropriate education program.

\section{Supplementary Education}

After graduation in medicine, the medical graduate, by virtue of his clinical training, has assets which enable him to influence medical colleagues when they place excessive demands on the laboratory. It is possible for him to have an interest in the interpretation of laboratory results, and thus to participate in the elaboration of certain diagnoses. On the other hand, he needs additional training in the scientific disciplines related to clinical chemistry. This notably refers to analy tical chemistry, statistics and biochemistry including human biochemistry. Clinical chemistry itself should be the subject of a practical and theoretical training including the biochemistry of clinical medicine. This involves the interpretation of both clinical and laboratory data. Knowledge of analytical clinical chemistry, in particular evaluation of methods and instruments and quality control are part of this training. Experience in laboratory management can be gained during service in a well organized clinical chemistry laboratory. Additional training, both practical and theoretical, should be acquired in hematology, clinical physiology, endocrinology and the use of isotopes. It is important that the medical graduate will have spent a total of at least six months in clinical wards, preferably internal medicine or pediatrics, becoming familiar with the application of laboratory findings to patient care.

After graduation in science, the science graduate holding a degree in chemistry or biochemistry approaches the subject of clinical chemistry with a good background in fundamental science and instrumentation. He generally will have done experimental research. In addition, it may be helpful for him to study the principles of electronics and to be trained in the use of computers.

What the science graduate principally lacks after his basic studies is a knowledge of the medical language and of the biochemical bases of diagnosis and therapeutics. He should supplement his bäckground by courses in biology, cell morphology, physical biochemistry and attain an expert knowledge in human biochemistry. He must understand the etiology and pathology of diseases showing chemical disturbances, and be familiar with drug therapy and metabolism.

As in the case of the medical graduate, he has to become acquainted with laboratory management and the various aspects of clinical chemistry.

After graduation in pharmacy, the basic education of the pharmacy graduate is quite variable in the different countries of the world. Programs have a duration ranging from three to five years. The supplementary education required for the specialist in clinical chemistry will thus depend on whether or not some essentials of clinical chemistry were already included in the undergraduate curriculum. Postgraduate education, sometimes available in schools of pharmacy, should include training at advanced levels in analytical chemistry, clinical chemistry, instrumentation and basic training in medical pathology, immunochemistry and hematology.

These were the supplementary schemes for training in clinical chemistry as recommended by the IUPAC Commission on the Teaching of Clinical Chemistry and the IFCC Committee on Education and Training in Clinical Chemistry.

\section{Undergraduate Training}

Some teaching in laboratory techniques has always been included in the normal medical studies. Formerly, this was done in the pre-clinical years by the department of physiological chemistry or of biochemistry. It is now increasingly evident that departments of basic biochemistry have to incorporate clinical chemists in their teaching staff if they wish to provide an appropriate education to medical students. Another system has been made possible by the creation of departments of clinical chemistry in some medical schools. These provide practical and theoretical courses of clinical chemistry during the clinical semesters.

Whatever the system is, the content of the teaching given to students in medicine is extremely important. A superficial training can provide the future practising doctor with the dangerous illusion that he is able to perform for himself a lot of determinations with no further concern. Whereas it is quite useful that he be trained for the execution of some simple and reliable tests, he should also be made aware of the difficulties encountered in laboratory work. He should be able 
to estimate the limits of his own capabilities, to know what a laboratory result means in terms of accuracy and precision, and what significance it has for the establishment of diagnosis or treatment.

If the clinical biochemistry department can organize courses on the interpretation of results, this can prove very helpful. A proper interpretation ensures that a good use is made of the laboratory services. All this shows that the clinical chemist has a role to play in the education of medical students, and that chairs of clinical chemistry, if they do not already exist, should be created in all the major medical schools.

Another aspect of undergraduate training is provided by the existence, in some countries, of undergraduate programs oriented towards laboratory work and ending with a diploma of clinical laboratory specialist. The justification of such a curriculum is still the subject of some controversy, since these graduates are not likely to reach the level provided by postgraduate training. In my opinion, such curricula are very useful, provided that they are not intended to substitute for postgraduate training.

\section{Training of Technicians and Technologists}

In general, laboratory technicians are educated so as to be capable of working indifferently in clinical chemistry, hematology, or microbiology. Some places offer curricula specific for clinical chemistry. An important requisite for the quality of such teaching is that the theoretical part fits well with the practical one.

If the technician understands the underlying principles of his work, this is more likely to be of good quality.

Advances in instrumentation, electronics, computers, chromatography and other methods have also resulted in a demand for highly skilled technologists specialized in such specific areas. This, of course, requires appropriate teaching, preferably given by people aware of the problems of the clinical laboratory.

\section{Training in Developing Countries}

Developing countries are faced with the difficult task of setting up a good health service with limited technical and financial means. This inevitably requires the choice of priorities. For laboratories, the best solution is probably to restrict the service to the essential while making sure that the quality is good. This is one area where teaching for clinical chemistry can be of great value.

This teaching must take into account the fact that developing countries have often problems of supply of reagents, electricity and water, and that repair and maintenance of sophisticated instruments is not easy. Thus, the teaching as practised in the industrial countries is not necessarily a useful model. The education must be centered on the understanding and proper use of those instruments and methods best adapted to the local conditions, with an appropriate training in quality control.

\section{Evolution and Needs}

My final remarks will concern the overall problems of the teachning in clinical chemistry. These problems are difficult, and are best characterized by two words: evolution and needs.

The evolution of clinical chemistry has been tremendous, and it still goes on. It has placed us in a situation we were not prepared for by our own studies: necessity to carry out a great number of analyses, development of new technologies and methods, progress in the use of laboratory data for diagnosis and treatment of disease. In front of this, we have to put the needs of modern health care and prevention. These are essentially: quality, significance, reasonable cost. These needs are the same in all countries of the world, but their fulfillment will vary depending on local conditions. Two conclusions we can draw at present are that the importance of the teaching in clinical chemistry is insufficiently understood in many medical schools and universities, and that this teaching should be promoted by the creation of chairs of clinical chemistry. It is also evident that clinical chemistry is a discipline requiring knowledge in quite different areas such as medicine, basic sciences and technology. Thus, the teaching in clinical chemistry is perhaps best ensured if it is given by different individuals possessing different backgrounds. So now let us evolve further and work hard to fulfill these needs.

\section{References}

1. Peters, J. P. \& Van Slyke, D. D. (1931/32), Quantitative Clinical Chemistry, Vol. I (1931) and II (1932), Baltimore, The Williams \& Wilkins Co.
2. Rubin, M. \& Lous, P. (1977), Education and Training for Clinical Chemistry, MTP Press Ltd, Lancaster, England.

Priv. Doz. Dr. Marc Roth Laboratoire Central

H6pital Cantonal

CH-1211 Geneve 4 
. 